\title{
FUNDAMENTAL ANALYSIS TECHNIC AND STOCK PRICE
}

\author{
Sofia Ulfa Eka Hadiyanti ${ }^{1 *}$, Praja Hadi Saputra ${ }^{2}$ \\ ${ }^{1,2}$ Universitas Muhammadiyah Kalimantan Timur, East Kalimantan, Indonesia \\ *Corresponding author: sueh433@umkt.ac.id
}

\begin{abstract}
This study aims to determine the effect of Price Earning Ratio, Earning Per Share, Price Book Value Ratio, Debt to Equity Ratio, and Net Profit Margin to stock prices in listed companies in the hotels, restaurants and tourism sub-sector in 2017 for 12 months. The sampling technique used in this study was a purposive sampling method, with the number of samples used in this study as many as 9 companies. The variables used in this study are Price Earning Ratio, Earning Per Share, Price Book Value Ratio, Debt to Equity Ratio, and Net Profit Margin as independent variables. Stock price as the dependent variable. The analysis method used in this study was multiple linear regression analysis. The hypothesis testing used the F test to test the effect of simultaneous variables and the t-test to test the coefficients partially with a significant level of 5\%. Besides that, the data normality test was also carried out by using the classic assumption test which includes autocorrelation test, multicolliniarity test, and heteroscedasticity test. The results of the analysis using multiple regression show that: Price Earning Ratio, Price Book Value, and Net Profit Margin have a positive effect on Stock Prices, while Earning Per Share and Debt to Equity Ratio have a negative effect on Stock Prices.
\end{abstract}

Keywords: stock price; leverage ratio; profitability ratio; market value ratio.

Received July ${ }^{24 \text { th }} 2019 \quad$ Revision June ${ }^{25 \text { th }} 2020 \quad$ Accepted for Publication July ${ }^{10 \text { th }} 2020$

\section{INTRODUCTION}

Investors in investing their funds need a variety of useful information to predict their investment returns in the capital market. Stocks are high return - high risk, stocks can provide high profit opportunities with high risk as well. Investors need to conduct stock analysis appropriately to minimize unexpected risks, both through technical and fundamental analysis. Technical analysis is an analysis of patterns of stock movements in the past through a chart to predict future price movements, while fundamental analysis is an analysis based on the financial performance of a company that is summarized in financial statements published annually. Analysis of financial statements using financial ratios can be used as consideration in determining stock prices.

Various kinds of risks arising from uncertainties in investing must be faced by investors. Because of this, investors need to know complete information in order to minimize or even avoid these kinds of risks. Basically, the level of profit and risk level is directly proportional. The higher the level of expected profits, the level of risk to be borne is also high.

Financial ratios are benchmarks that are often used by investors in making decisions for investment because they connect two financial data in financial statements. Analysis and interpretation of various financial ratios can provide a better and better view of financial condition and company performance for experienced and experienced analysts than analyzes 
based solely on individual financial data that are not ratios (Horne, 1995) in (Sawir , 2003). Ratios are grouped into 5 basic groups, namely: liquidity, leverage, activity, profitability, and market value. This study used 3 categories of ratios namely leverage ratio, market value ratio and profitability ratio.

The leverage ratio shows the company's ability to meet all financial obligations if the company is currently liquidated (Sawir, 2003). Leverage ratio that are commonly used are Debt to Total Asset Ratio, Debt to Equity Ratio, Time Interest Earn, and Fixed Charge Coverage. This study used Debt to Equity Ratio (DER). DER is a debt ratio measured by the ratio of debt to equity (equity). A safe DER level is usually less than 50 percent. The smaller the DER, the better the company would be, it means that some of the company's capital structure consists of equity so that financial risk is low, this can increase share prices on the capital market.

Market value ratio are the most comprehensive measure to assess the results of a company's work, because these ratios reflect a combination of the effect of risk and the ratio of returns (Sawir, 2003). Commonly used valuation ratios are Price to Earning Ratio, Price Book Value Ratio, and Earning per Share. In this study using Price to Earning Ratio (PER), Price Book Value Ratio (PBV) and Earning per Share (EPS). Variable Price Earning Ratio (PER) is a ratio that shows the comparison between stock prices with net income for each share outstanding. PER is also used to calculate the rate of return on capital invested in a stock or calculate the ability of a stock to generate profits. Investors believe that a company will have a promising future if it has a high PER. Therefore, a high PER is a positive signal that can attract investors to buy shares so that it can affect the stock price. PBV functions the same as PER, which is to calculate the fair price of a company's shares, but PER is more focused on net income, while PBV is more focused on calculating equity. The amount of profit earned by investors per share can be seen from Earning Per Share (EPS). The higher the EPS, the higher the profits received by investors per share owned. This will cause investors to be interested in buying these shares. The interest of investors to buy shares in a company will cause the price of shares in a company will tend to increase.

Profitability ratio is the ability of a company to make a profit in relation to sales, total assets and own capital (Sartono, 2001). Commonly used profitability ratios are Gross Profit Margin, Net Profit Margin, Return On Assets, and Return On Equity. In this study using Net Profit Margin (NPM). The variable Net Profit Margin (NPM) shows the company's ability to generate income from interest by looking at the company's performance in disbursing loans, bearing in mind the company's operating income is highly dependent on the difference in interest from the credit channeled. The higher the NPM can increase the stock price because shares favored by investors are shares that the company is healthy that is able to generate high profits and it can be understood that by increasing NPM will increase earnings for the company so that it will increase shareholder income. 
Indonesia is an archipelago that has many tourist attractions that are able to attract domestic and foreign tourists. The beauty of Indonesia makes many local and foreign investors roll in to invest in Indonesia. Many countries are of the opinion that international tourism is an important factor in the national economy and is considered an invisible export that can strengthen the balance of payments. Databoks.co.id stated that the realization of investment in the tourism sector reached Rp 20.9 trillion in 2017 and is dominated by the hotel and restaurant sector. This proves that the restaurant, hotel and tourism industries have favorable prospects for investors. So the restaurant, hotel and tourism sub-sectors are interesting to study.

Based on this, the researcher chose the fundamental analysis technique as a technique for analyzing stock prices in listed companies in the hotel, restaurant and tourism sub-sector by selecting 5 (five) variables in the study namely Price Earning Ratio (PER), Earning Per Share (EPS), Price Book Value Ratio (PBV), Debt to Equity Ratio (DER), and Net Profit Margin (NPM). Researchers are interested in taking the object of research in the hotel, restaurant and tourism sectors because it is still very rarely found as a research object.

\section{Hypothesis Development}

According to (Tryfino,2009), Price Earning Ratio (PER) is the ratio used to calculate the rate of return on capital invested in a stock. Or, calculate the ability of two stocks to generate profits. The aim is to predict when or how many times the profit the company makes compared to its share price in a certain period. The smaller the PER of a stock, the better it can be concluded that the PER ratio has an inverse effect on stock prices. Logically, the rate of return on investment in these shares will be faster because the EPS generated is getting bigger. Sihombing (2008) said that PER is a comparison of the price of shares with net income for each share of the company. PER is a cheap or expensive measure of a stock, when compared to other stock prices for a similar industry. It can be hypothesized as follows:

\section{$\mathrm{H}_{1}$ : It is expected there are positive influence between the PER to stock price}

According (Tandelilin,2001), Information earnings per share or better known as the Earning Per Share (EPS) of a company shows the amount of net income of companies who are ready to share the all company shareholders. The amount of EPS of a company can be known from the company's financial statement information such as balance sheet and income statement. The higher the value of EPS is certainly encouraging shareholders because the greater the profit provided to shareholders. According to Samsul (2006), buying shares means buying the company's prospects, which is reflected in earnings per share (EPS). If earnings per share are higher, then the company's prospects are better, while if earnings per share is lower, it means that it is not good, and negative earnings per share is not good. With the reduced demand for the company's shares, the share price will go down and the company's 
stock income will also fall. Based on the above theory, it can be concluded that if a company's EPS is high, the dividends and capital gains obtained are also high. Stock companies that provide high dividends and capital gains will be in demand by investors, causing share prices to rise. It can be hypothesized as follows:

\section{$H_{2}$ : It is expected there are positive influence between EPS on stock prices}

According (Tryfino,2009), Price to Book Value (PBV) is a computation or comparison between the market value of the book value of a share. This ratio serves to complete the analysis book value. If in the analysis book value, investors only know the capacity per share of the value of shares, in the PBV ratio investors can find out directly how many times the market value of a stock is valued from its book value. Sihombing (2008) argues that Price to Book Value (PBV) is a value that can be used to compare whether a stock is more expensive or cheaper compared to other shares. To compare, the two companies must be from one business group that has the same business nature. This ratio can give a picture of the potential price movement of a stock so that from this picture, indirectly this PBV ratio also gives an influence on stock prices. Then it can be hypothesized as follows:

\section{$\mathrm{H}_{3}$ : It is expected there is a positive influence between PBV on stock prices}

According to (Darsono \& Ashari,2005), Debt to Equity Ratio (DER) shows the percentage of the provision of funds by shareholders to the lender. The higher the ratio, the lower the company's funding provided by shareholders, and vice versa, the lower this ratio the better the company's ability to pay long-term obligations. This makes the company's stock price rise. Creditors prefer smaller DER numbers. If DER is high, most of the company's capital structure consists of long-term loans so that the company's financial risk is high and will result in a decline in the stock price in the capital market. Based on the above theory it is concluded that if the company's DER is low, then the investor will respond positively and see the risk of the company in paying off debt will be small so that the interest in buying the company's shares will be high, and the company's stock price will rise and share income will also rise. So Debt to Equity Ratio is negatively related to stock income. It can be hypothesized as follows:

\section{$\mathrm{H}_{4}$ : It is expected there are positive influence between the DER to the stock price}

According to (Sutrisno,2001), the greater the Net Profit Margin (NPM), the better the company to generate profits compared with the sales achieved and investors will be more interested in making stock prices go up. According to (Mais,2005), a high Net Profit Margin (NPM) can increase share prices because shares favored by investors are stocks that are healthy companies that have the ability to generate high profits and can be understood that by increasing NPM, it will increase shareholder wealth. . Based on the above theory it can be 
concluded, investors like high levels of NPM because high NPM shows that the company is able to generate high profits. It can be hypothesized as follows:

\section{Hs: Presumably there are positive influence between the NPM to the stock price}

Several previous studies showed that the analysis of financial ratios have a significant effect on stock prices. According to (Yosua,2012), in his research on the effect of PBV, PER, NPM on stock prices in banking companies shows that PBV affects stock prices, whereas PBV and PER have no effect on stock prices. In addition, other financial ratios such as EPS and DER are also thought to have an effect on stock prices simultaneously, as in (Sari $\&$ Santosos,2017). Then it can be hypothesized as follows:

H6: It is expected there is a simultaneous influence between PER, EPS, DER, PBV and NPM on stock prices

\section{RESEARCH METHODS}

\section{Population and Samples}

The population in this study are hotel, restaurant and tourism sub-sector companies listed on the Stock Exchange Indonesia in 2017. Purposive sampling is deliberate sampling of populations based on certain assessments or criteria. The sample criteria in this study are as follows:

a. Hotel, restaurant, and tourism sub-sector companies listed on the IDX during 2017.

b. The hotel, restaurant, and tourism sub-sector companies that issued financial statements for 2017 (12 months).

c. Companies that provide data in accordance with research variables.

The sample in this study is the hotel, restaurant, and tourism sub-sector companies listed on the Indonesia Stock Exchange in 2017, as many as 9 companies. The sample list of companies listed on the Indonesia Stock Exchange, namely:

a. Bayu Buana Tbk

b. Fast Food Indonesia Tbk

c. Indonesian Paradise Property Tbk

d. Jakarta Setiabudi International Tbk

e. Mas Murni Indonesia Tbk

f. Graha Lestari IndahTbk

g. DevelopmentJaya Jaya Ancol Development

h. Saraswati Griya Lestari Tbk

i. Pudjiadi Prestige Tbk

\section{Regression Analysis Multiple}


It is used to determine the effect of several independent variables on the dependent variable. This study uses independent variables, namely PER, EPS, PBV, DER, and NPM. The dependent variable in this study is the stock price. The multiple regression equation used is as follows:

$$
Y=\alpha+\beta_{1} X_{1}+\beta_{2} X_{2}+\beta_{3} X_{3}+\beta_{4} X_{4}+\beta_{5} X_{5}+e
$$

Description:

$$
\begin{array}{cl}
Y & =\text { Stock Price } \\
\alpha & =\text { Constant } \\
\beta_{1}, \beta_{2}, \beta_{3}, \beta_{4}, \beta_{5} & =\text { Regression coefficient of the independent variable } \\
X_{1} & =\text { PER } \\
X_{2} & =\text { EPS } \\
X_{3} & =\text { PBV } \\
X_{4} & =\text { DER } \\
X_{5} & =\text { NPM } \\
e & =\text { Confounding factor }
\end{array}
$$

\section{Hypothesis}

a. F-test

The F-test is used to find out how the influence of the independent variable on variables are bound together. F test for testing in research can be viewed through probabilities/ significance (Santoso, 2002) with the following conditions:

If the probability $<\alpha 0.05$ then $\mathrm{H}_{0}$ is rejected and $\mathrm{H}_{1}$ is accepted

If the probability $>\alpha 0.05$ then $\mathrm{H}_{0}$ is accepted and $\mathrm{H}_{1}$ is rejected b. t-test

The t-test is used to test whether the hypothesis statement is true. The t-test basically shows how far the influence of an independent variable individually in explaining the dependent variable. For testing using the $\mathrm{t}$ test in this study seen through the probability / significance $\alpha=0.05$. (Santoso, 2002)

If the probability $<\alpha 0.05$ then $\mathrm{H}_{0}$ is rejected and $\mathrm{H}_{1}$ is accepted

If the probability $>\alpha 0.05$ then $\mathrm{H}_{0}$ is accepted and $\mathrm{H}_{1}$ is rejected

\section{Classical Assumption Test}

Classical assumption test used in this study includes:

a. Multicolliniarity Test

According to (Gozali,2018), the multicollinearity test aims to test whether the regression model found a correlation between independent variables. To find the presence or 
absence of multicollinearity in the regression model, it can be seen from the value of the variance inflation factor (VIF) and tolerance measures of the selected independent variable that cannot be explained by other independent variables. So low tolerance is equal to a high $\mathrm{VIF}$ value (because VIF $=1$ /tolerance) and this shows a high degree of collaterality. The cutoff value commonly used is tolerance $>0.01$ or equal to the VIF value $<10$

b. . Heteroscedasticity Test

According to (Ghozali, 2018), the heteroscedasticity test aims to test whether in a regression model, a variance difference occurs from the residuals of one observation to observation other. If the variance from one observation residual to another observation remains, then it is called homoscedasticity or heteroscedasticity does not occur and if it is different then it is called heteroscedasticity. A good regression model that does not occur heteroscedasticity. The basis of decision making is as follows:

- If there are certain patterns, such as the points that form a certain pattern that is regular (wavy, widened and then narrowed), then heteroscedasticity occurs

- If there is no clear pattern, such as points spreading above and below number 0 on the $\mathrm{Y}$ axis, then there is no heteroscedasticity.

c. Autocorrelation Test

According to (Ghozali,2018), autocorrelation arises because sequential observations over time relate to one another. This problem arises because residuals are not free from one observation to another. A good regression model is a regression model that is free from autocorrelation. The way to detect the presence or absence of autocorrelation is to run test.

The run test is part of the non-parametric statistics may be used to test whether there is a correlation between high residual. If there is no correlation between residuals then it is said that the residual is random or random.

According to (Ghozali,2018), the basis for making statistical test decisions with run tests is as follows:

- If the value of Asymp. Sig (2-tailed) is less than $0.05(<0.05)$ then $\mathrm{H}_{1}$ is rejected and $\mathrm{H}_{0}$ is accepted. This means that residual data occur not randomly (systematically).

- If the Asymp value. Sig (2-tailed) is more than 0.05 (> 0.05) then $\mathrm{H}_{1}$ is accepted and $\mathrm{H}_{0}$ is rejected. This means that residual data occur randomly.

d. Normality Test

According to (Ghozali,2018) normality test is carried out to test whether in the regression model, confounding or residual variables have a normal distribution. If the variables are not normally distributed then the statistical test results will decrease. The way to detect whether residuals are normally distributed or not can be done by looking at the normal probabilities plot. Decision making as follows: 
- If the data spreads around the diagonal line and follows the direction of the diagonal line or the histogram graph shows a normal distribution pattern, then the regression model meets the normal assumptions.

- If the data spreads far from the diagonal line or does not follow the direction of the diagonal line or the histogram graph does not show a normal distribution pattern, then the regression model does not meet the normal assumptions.

\section{RESEARCH AND DISCUSSION}

This multiple regression analysis was carried out to calculate the magnitude of influence between independent variables consisting of PER, EPS, PBV, DER, and NPM on the dependent variable namely stock prices. From the analysis using SPSS program, the following results are obtained:

\section{Table 1}

Regression Analysis

\begin{tabular}{|c|c|c|c|c|}
\hline Variable & B & $\mathbf{T}$ & $\operatorname{Sig} \mathbf{t}$ & Description \\
\hline Constants & -278.808 & & & \\
\hline PER & 8,905 & 6,925 & 0,000 & Significant \\
\hline EPS & $-0,131$ & $-0,499$ & 0,619 & Not Significant \\
\hline PBV & 791,634 & 13,196 & 0,000 & Significant \\
\hline DER & $-307,900$ & $-3,258$ & 0,002 & Significant \\
\hline NPM & 7,366 & 1,104 & 0,272 & Not Significant \\
\hline R Square & $=$ & 0,794 & & \\
\hline $\mathrm{F}$ & $=$ & 78,440 & & \\
\hline Sig F & $=$ & 0,000 & & \\
\hline
\end{tabular}

From the results above, it can be written in the form of a regression equation as follows:

$$
Y=-278,808+8,905 \mathrm{X}_{1}-0,131 \mathrm{X}_{2}+791,634 \mathrm{X}_{3}-307,900 \mathrm{X}_{4}+7,366 \mathrm{X}_{5}
$$

From the equations and table, it can be seen that:

a. The constant value obtained is $-278,808$. This means that if the independent variable (PER, EPS, PBV, DER, NPM) does not exist, then the independent variable (Share Price) has decreased by 278,808 .

b. Value of the coefficient regression variable PER $\left(X_{1}\right)$ of 8.905. This shows that each increase in one PER will result in an increase in Share Price of 8,905.

c. The EPS variable regression coefficient $\left(X_{2}\right)$ is -0.131 . This shows that every increase of one EPS unit will result in a decrease in Share Price of 0.131.

d. PBV variable regression coefficient $\left(X_{3}\right)$ is 791,634 . This shows that each increase of one unit of PBV will result in an increase in Share Price of 791,634.

e. The DER variable regression coefficient $\left(X_{4}\right)$ value is $-307,900$. This shows that every increase of one unit of DER will result in a decrease in Stock Price of 307,900. 
f. The value of the regression coefficient of the variable NPM $\left(X_{5}\right)$ was 7.366. This shows that every increase of one unit of NPM will result in an increase in Share Price of 7,366.

g. From the equation above there is a correlation between the independent variable and the dependent variable which means the relationship between all the independent variables (PER, EPS, PBV, DER, NPM) is very close or very strong that is equal to $79.4 \%$, while the remaining $20.6 \%$ is influenced by variables other than this research variable.

h. Simultaneously, it can be seen from the Sig F value $<5 \%(0,000<0.05)$. The point is that PER, EPS, PBV, DER, and NPM simultaneously have a significant effect on stock prices.

i. Partially, EPS and NPM have no significant effect on stock prices seen from sig $\mathrm{t}>5 \%$, i.e. (0.619>0.05; 0.272>0.05). While PER, PBV, and DER variables have a significant effect on stock prices, seen from sig t, $5 \%(0.00<0.05 ; 0.000<0.05 ; 0.002<0.05)$.

The results of the classic assumption test can be described as follows:

a. Multicollinearity Test Results

\section{Table 2}

Multicolliniarity Test

\begin{tabular}{|c|c|c|c|c|c|c|c|}
\hline \multicolumn{8}{|c|}{ Coefficients $^{\mathrm{a}}$} \\
\hline \multirow[b]{2}{*}{ Model } & \multicolumn{2}{|c|}{$\begin{array}{l}\text { Unstandardized } \\
\text { Coefficients }\end{array}$} & \multirow{2}{*}{$\begin{array}{c}\text { Standardized } \\
\text { Coefficients } \\
\text { Beta }\end{array}$} & \multirow[b]{2}{*}{$\mathrm{T}$} & \multirow[b]{2}{*}{ Sig. } & \multicolumn{2}{|c|}{ Collinearity Statistics } \\
\hline & $\mathrm{B}$ & Std. Error & & & & Tolerance & VIF \\
\hline 1 (Constant) & -278.808 & 108.877 & & -2.561 & .012 & & \\
\hline PER & 8.905 & 1.286 & .395 & 6.925 & .000 & .622 & 1.608 \\
\hline EPS & -.131 & .263 & -.026 & -.499 & .619 & .772 & 1.296 \\
\hline PBV & 791.634 & 59.990 & .658 & 13.196 & .000 & .814 & 1.228 \\
\hline DER & -307.900 & 94.501 & -.164 & -3.258 & .002 & .798 & 1.253 \\
\hline NPM & 7.366 & 6.674 & .057 & 1.104 & .272 & .768 & 1.302 \\
\hline
\end{tabular}

a. Dependent Variable: Stock Price

The results of the calculation of the tolerance value of each variable is greater than 0.10 , namely $0.622 ; .772 ; 0.814 ; 0.798 ; 0.768$ and the VIF value of each variable smaller than 10 is 1,$622 ; 1,608 ; 1,228 ; 1,253 ; 1,302$ so that it can be concluded that data multicollinearity does not occur between independent variables.

b. Heteroscedasticity Test Results 


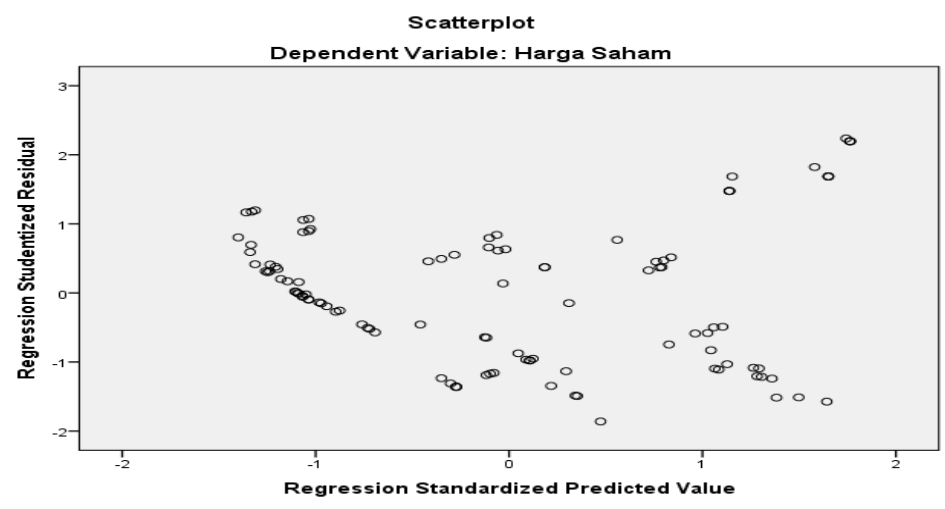

Figure 1

Heteroscedasticity Test

Based on the picture above, the points spread randomly and evenly on the $\mathrm{X}$ and $\mathrm{Y}$ axes, they are not gathered in one certain place and do not form a particular pattern. So it can be concluded that there is no heteroscedasticity between independent variables.

c. Autocorrelation Test Results

Table 3

Autocorrelation

\begin{tabular}{lr}
\hline \multicolumn{2}{c}{ Runs Test } \\
\hline & $\begin{array}{c}\text { Unstandardized } \\
\text { Residual }\end{array}$ \\
\hline Test Value $^{\mathrm{a}}$ & -2.20735 \\
Cases < Test Value & 54 \\
Cases >= Test Value & 54 \\
Total Cases & 108 \\
Number of Runs & 56 \\
Z & .193 \\
Asymp. Sig. (2-tailed) & .847 \\
\hline a. Median & \\
\hline
\end{tabular}

Based on the table above, the Asymp value. Sig. (2-tailed) in the run test resulted in 0.847 which means that the value is greater than $0.05(0.847>0.05)$, it can be concluded that there is no autocorrelation between the independent variables. 
d. Normality Test Results

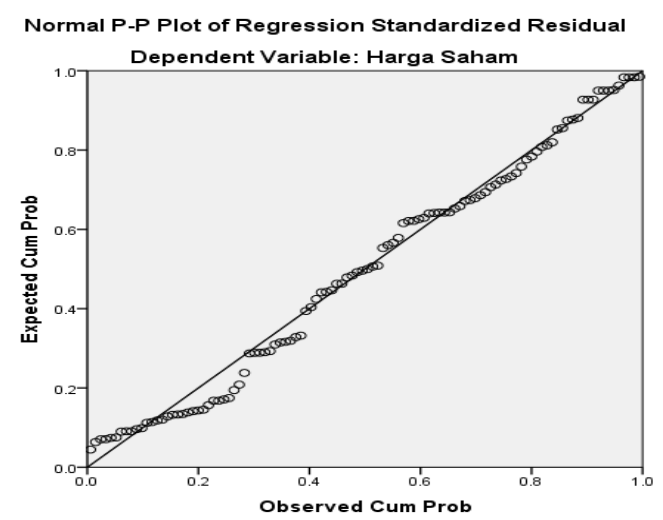

Figure 2

Test for Normality

Given the image above, the points spread around the line and follow the diagonal line, then it can be concluded that the test results have been normally distributed.

\section{Discussion}

\section{The Effect of Price Earning Ratio (PER) on Stock Prices}

Based on the results of data analysis in multiple regression, the results show that PER (Price Earning Ratio) has a positive influence on stock prices. This is indicated by the positive regression coefficient. This means that any increase in PER will raise share prices. The market or investors are very interested in investing in a company that has a high growth rate. This shows that the market expects profit growth in the future. The low value of PER is not caused by the stock price which tends to decrease but is caused by the increase in the company's net profit. So, the lower the PER value, the cheaper the shares to be purchased and the better the performance per share in generating net profits of the company so that it affects many investors to buy these shares. The results of this study also support the results of research conducted by (Oktaviani,2017).

\section{Effect of Earning Per Share (EPS) on Stock Prices}

Based on the results of data analysis in multiple regression, the results show that EPS (Earning Per Share) has a negative influence on stock prices. This is indicated by the negative regression coefficient. This means that any decline in EPS will raise share prices, and vice versa. In general, company management, ordinary shareholders and potential shareholders are very interested in EPS, because EPS is one indicator of the company's success. Investors really need EPS information of a company that shows the amount of the company's net profit that is ready to be distributed to all the company's shareholders. So, the higher this ratio figure, it illustrates the amount of rupiah obtained for each common stock and illustrates the prospect of earnings company in the future, so investors are interested in investing in 
companies with high EPS values. The results of this study also support the results of research conducted by (Novasari,2013).

\section{Effect of Price Book Value (PBV) on Stock Prices}

Based on the results of data analysis in multiple regression, the results show that PBV (Price Book Value) has a positive effect on stock prices. This is indicated by the positive regression coefficient. This means that any increase in PBV will increase the stock price. Indeed, there is no exact measure of whether or not a stock price is measured by its PBV ratio because it really depends on the expectations and performance of the company or shares. But at least this ratio can give a picture of the potential price movement of a stock, the intention is that if a stock that performs well turns out its PBV is still low compared to the average PBV of shares in the sector, the price of the stock still has the potential to rise, and vice versa. The results of this study also support the results of research conducted by (Cahyaningrum,2013).

\section{Effect of Debt to Equity Ratio (DER) on Stock Prices}

Based on the results of data analysis in multiple regression, the results show that DER (Debt to Equity Ratio) has a negative influence on stock prices. This is indicated by the negative regression coefficient. This means that any decrease in DER will increase share prices, and vice versa. The results of this analysis indicate that the DER value is high so that it has a negative effect on stock prices. It can be explained that if the DER value is high, this indicates that the capital structure of the business is making more use of debt relative to equity. The higher the DER reflects the relatively high risk of the company because the company in operation is relatively dependent on debt and the company has the obligation to pay debt interest as a result investors tend to avoid and are not interested in company shares that have a high DER value. The results of this study also support the results of research conducted by (Dewi \& Suaryana,2013).

\section{Effect of Net Profit Margin (NPM) on Stock Prices}

Based on the results of data analysis in multiple regression, the results show that NPM (Net Profit Margin) has a positive effect on stock prices. This is indicated by the positive regression coefficient. This means that each increase in NPM will increase share prices. If the company has the ability to generate net profits, then investors will be interested in buying these shares, this will cause market prices to rise. The results of this study also support the results of research conducted by (Watung \& Ilat,2016).

\section{Effect of PER, EPS, PBV, DER, and NPMStock Prices}

Based on the results of data analysis in multiple regression, the results show that PER, EPS, PBV, DER and NPM simultaneously influence the stock prices. This result is 
indicated by the significance value which is smaller than the probability $(0.00<0.05)$. While the magnitude of the level of influence between variables is also quite strong at $79.4 \%$ which means PER, EPS, PBV, DER and NPM are sufficient to measure the level of reasonableness and expectations of stock prices.

\section{CONCLUSION}

Partially, there is a positive influence between PER, PBV and NPM on stock prices; and there is a negative influence between EPS and DER on stock prices. Simultaneously, there is an influence between PER, EPS, PBV, DER and NPM on stock prices.

\section{REFERENCES}

Darsono \& Ashari. (2005). Practical Guidelines for Understanding Financial Statements. Jakarta. Salemba Empat

Ghozali, I. (2007). Multivarate Analysis with SPSS Program, Matter Four. Semarang. DiponegoroUniversity Publishing Board

Gujarati, D., \& Zain, S. (2004). Ekonometrika Dasar. Jakarta. Erlangga

Indriantoro \& Supomo. (2002). Metodologi Penelitian Bisnis Edisi Pertama, Cetakan Kedua. Yogyakarta. BPFE

Iqbal, H. M. (2002). Pokok - Pokok Materi Statistik 2 (Statistik Inferensif). Jakarta. Bumi Aksara.

Mais, R. G. (2006). Pengaruh Rasio-Rasio Keuangan Utama Perusahaan Terhadap Harga Saham Perusahaan Yang Terdaftar di Jakarta Islamic Index Tahun 2004. Tesis. Fakultas Pascasarjana, Universitas Indonesia.

Novasari, E. (2013). Pengaruh PER, EPS, ROA, Dan DER Terhadap Harga Saham Perusahaan Sub Sektor Industri Textile Yang Go Public Di Bursa Efek Indonesia Tahun 2009-2011, Skripsi. Universitas Negeri Semarang

Oktaviani, P. S. (2017). Pengaruh PER, EPS, DPS, DPR Terhadap Harga Saham Pada Perusahaan Pertambangan, Jurnal Ilmu Dan Riset Manajemen, Vol 6, No 2.

Samsul, M. (2006). Pasar Modal dan Manajemen Portofolio. Jakarta. Erlangga.

Santoso, S. (2002). Buku Latihan SPSS Statistik Parametrik. Jakarta. PT Alex Media Komputindo

Sari, L. A., \& Santoso, B. H. (2017). Pengaruh EPS, DER, PBV, Dan NPM Terhadap Harga Saham Perusahaan Properti, Jurnal Ilmu dan Riset Manajemen, Vol 6. No 8.

Sartono, A. (2001). Financial Management Theories and Applications. Yogyakarta. BPFE

Sawir, A. (2003). Financial Performance Analysis and Corporate Financial Planning. Jakarta. PT Gramedia Pustaka Utama

Sihombing, G. (2008). Kaya dan Pinter Jadi Trader \& Investor Saham. Yogyakarta. Indonesia Cerdas 
Suaryana \& Putu. (2013). Pengaruh EPS, DER, Dan PBV Terhadap Harga Saham, E-Jurnal Akuntansi Universitas Udayana.

Sugiyono. (2010). Metode Penelitian Pendidikan Pendekatan Kuantitatif, Kualitatif, dan $R \& D$. Bandung. Alfabeta

Suliyanto. (2005). Analisis Data dalam Aplikasi Pemasaran. Bogor. Ghalia Indonesia

Supranto, J. (2000). Statistik (Teori dan Aplikasi) Edisi Keenam. Jakarta. Erlangga

Sutrisno. (2001). Manajemen Keuangan, Edisi Pertama. Yogyakarta. BPFE

Tandelilin, E. (2001). Analisis Investasi dan Manajemen Portofolio, Edisi Pertama. Yogyakarta. BPFE

Tryfino. (2009). Cara Cerdas Berinvestasi Saham. Jakarta. Transmedia Pustaka

Ventje \& Rosdian. (2016). Pengaruh ROA, NPM, EPS Terhadap Harga Saham Pada Perusahaan Perbankan di BEI Periode 2011-2015, Jurnal EMBA, Vol 4 No 2.

Vincent, G. (1991). Applied Econometrics, Volume 1. Bandung. Tarsito

Yosua, E. S. (2012). Pengaruh ROA, ROE, PBV, PER, NPM, OPM Terhadap Harga Saham Perusahaan Perbankan Pada Tahun 2008 - 2011. Skripsi. Fakultas Ekonomi \& Bisnis. Universitas Dian Nuswantoro. 